\title{
Abundance of Associated Arbuscular Mycorrhizal Fungi with Pioneer Plants in Affected Area by Mount Merapi Eruption
}

\author{
Oktira Roka Aji ${ }^{1,3}$, Inggita Utami ${ }^{2,33^{*}}$, Cucu Cahyanti ${ }^{3}$ \\ ${ }^{1}$ Laboratory of Microbiology, Universitas Ahmad Dahlan, Jl. Ahmad Yani, Bantul, D.I. Yogyakarta, Indonesia 55191 \\ ${ }^{2}$ Laboratory of Ecology and Systematics, Universitas Ahmad Dahlan, Jl. Ahmad Yani, Bantul, \\ D.I. Yogyakarta, Indonesia 55191 \\ ${ }^{3}$ Biology Department, Faculty of Applied Science and Technology, Universitas Ahmad Dahlan, Jl. Ahmad Yani, Bantul, \\ D.I. Yogyakarta, Indonesia 55191
}

Received December 30, 2020/Accepted June 24, 2021

\begin{abstract}
Arbuscular mycorrhizal fungi (AMF) with mutualism symbiosis with plants are associated with the Fabaceae family's pioneer plants. This study aims to determine the percentage of AMF in the roots and the AMF spore's abundance in the rhizosphere of pioneer plants Calopogonium mucunoides Desv. and Vigna unguiculata (L.) Walp in Mount Merapi National Park after the 2010 eruption. The methods used for root infection analysis were slide methods and root staining, while spore analysis was wet sieving methods. The results showed the highest percentage of AMF infection in C. mucunoides root was found in an area with moderate damage. The highest percentage of AMF infection in V. unguiculata was found in an area with minor damage. The highest number of spores in the two plants' rhizosphere soil was found in an area with minor damage with an average of 10.4 and 9. The levels of damage by Mount Merapi's eruption did not significantly affect the percentage of AMF infection and the number of spores. Glomus dominates all study sites in both plants. Soil organic carbon is one of the abiotic factors correlated with the number of spores in rhizosphere soil.
\end{abstract}

Keywords: calopogonium, Merapi, mycorrhizal, succession, vigna

*Correspondence author, email: inggitautami@bio.uad.ac.id, tel. +62-274-563515, fax. +62-274-564604

\section{Introduction}

Forest damage due to land-use change and natural disturbances can reduce the abundance of microorganisms in the soil (Suriadikarta et al., 2011). Soil microorganisms influence the plant community's structure above the soil surface (Horn et al., 2017). Arbuscular mycorrhizal fungi (AMF) are the essential microscopic fungi in the soil (Gao et al., 2019), which have mutualism in $70 \%$ to $90 \%$ of plants (Mulyana \& Asmarahman, 2012; Taylor et al., 2017). AMF, as an obligate parasitic microorganism, will absorb nutrients from the roots of the host plant through its internal hyphae (Talanca, 2010; Munarti et al., 2018). In contrast, external hyphae help increase the nutrition uptake of nitrogen $(\mathrm{N})$ and phosphorus (P) to the host plant (Karti et al., 2018), expand the water absorption area (Suharno et al., 2014), and increase plant tolerance to heavy metals in the soil (Dewi et al. 2014; Ferrol et al., 2016). AMF, which dominates the most terrestrial ecosystems (Dell, 2002), can provide other ecological function such as protecting vegetation against drought and water stress (Chitarra et al., 2016), protection from soil pathogens, increasing plant diversity (Dodd, 2000), and increasing the survival rate of plants in critical land (Ulfa et al., 2006; Suharno \& Sancayaningsih, 2013 Saputri \& Suwirmen, 2016). AMF plays an essential role for the ecosystem services and land management in the natural and agricultural ecosystem (Barea et al., 2011; Chen et al., 2018) by inoculating specific AMF on pioneer plants or managing indigenous AMF to optimize vegetation communities' growth (Syamsiyah et al., 2014; Cely et al., 2016; Putra et al., 2020). AMF external hyphae with a diameter of $2-5 \mu \mathrm{m}$ can penetrate soil pores that cannot be penetrated by root hairs with a diameter of 10-20 $\mu \mathrm{m}$ (Pujiastuti, 2018). AMF spores, commonly found in the rhizosphere layer or around the roots of host plants (Sukmadi, 2013), will be stimulated by strigolactones from the roots exudation to germinate to form hyphal branches (Yurisman et al., 2015). AMF is recognized by spores, internal hyphae, external hyphae, and other structures, namely the arbuscular and vesicles (Muryati et al., 2016).

Mount Merapi is the most active volcano of Indonesia's 129 volcanoes (Newhall et al., 2000). The big eruption in 2010 was the most significant in the last 150 years (Marfai et al., 2012; Voight et al., 2000). According to Gunawan et al. (2013) and Marhaento and Kurnia (2015), the pyroclastic flow that spread as far as $13 \mathrm{~km}$ with differences in intensity has caused forests in the Mount Merapi National Park (MMNP) to be divided into three damage types: heavy damage (vegetation and soil substrate destroyed), moderate damage (sixty percent of vegetation burned), and minor damage (forests were only exposed to volcanic dush). After ten years of eruption, the forests in MMNP began to carry out succession with high stands in various areas (Gunawan et al., 2013; Afrianto et al., 2016; Parwati et al., 2019; Sutomo, 2019). However, despite there is an association of AMF with 
stands, these are still underreported. The presence of endo mycorrhizae has been published exactly one year after the 2010 eruption, where only 3 out of 12 pioneers were identified to be associated with the genus Acaulospora, Gigaspora, Glomus (Agus \& Wulandari, 2012). According to Klironomos et al. (2001) and Kivlin et al. (2011), AMF is distributed in an almost terrestrial ecosystem with variations in latitude and longitude, where temperature and humidity affect the dominance of AMF taxa in each location. Stands from the Fabaceae family began to dominate the Merapi forest with severe damage because they were tolerant with acidic soil conditions (Purwanto, 2007; Mensah, 2015) and hot substrates from the eruption (Sutomo, 2019). According to Requena et al. (2001), Pahan (2006), and Belay et al. (2013), the Fabaceae family's ability to survive in critical land is a result from mutualism with AMF, which will increase phosphorus uptake, water and increase fixation.

The succession of vegetation above the soil surface is thought to be correlated with an increase in the abundance of soil microorganisms (Suriadikarta et al., 2011). The magnitude of the disturbance at the beginning will affect the succession (Sutomo, 2019; Utami et al., 2021a; Utami et al., 2021b). The development of the AMF number both infecting pioneer plants and soil at various post-eruption damage levels is interesting to be studied as a preliminary investigation into soil microorganism succession development. Pioneer plants from the Fabaceae family, such as Calopogonium mucunoides Desv. and Vigna unguiculata (L.) Walp. were chosen because they are a local plant in the MMNP forest area throughout the affected area (Hariani \& Erlita, 2016; Muryati et al., 2017). Both plants are mycotrophic species that quickly produce biomass and are commonly used for phytoremediation in degraded areas (Khan, 2005; De-Souza et al., 2012). These two pioneer plants are also classified as legume cover crops (LCC) (Sajimin et al., 2017), which can reduce soil temperature, improve soil fertility, and control weeds (Solomon et al., 2014). This study aimed to determine the percentage of AMF infection in the roots and spore's abundance in the rhizosphere of the pioneer plant $C$. mucunoides Desv. and $V$. unguiculata (L.) Walp in varying levels of damage found in MMNP. This research is essential to identify the specific AMF associated with pioneer plants that developed during the succession in MMNP. The benefits of this research can add information to the presence of AMF in MMNP ecosystem rehabilitation processes by planting local pioneer plants from locations with the most optimum AMF abundance.

\section{Methods}

Location determination and sampling This research was conducted from October 2019 to March 2020, approximately ten years after the major eruption of Mount Merapi in 2010. Samples were taken from MMNP in the Special Region of Yogyakarta Province at Sleman Regency (Figure 1). The sampling location is in the MMNP forest, which was affected by the 2010 Merapi eruption with the level of heavy damage at point $\mathrm{H}\left(\mathrm{S} 07^{\circ} 34.689^{\prime} \mathrm{E} 110^{\circ} 26.560^{\prime}\right)$, the level of moderate damage at point $\mathrm{Mo}\left(\mathrm{S} 07^{\circ} 35.840^{\prime} \mathrm{E} 110^{\circ} 26.120^{\prime}\right)$, and the level of minor damage at point $\mathrm{Mi}$ (S07 $35.005^{\prime}$ E110 ${ }^{\circ} 4.961^{\prime}$ ) (Figure 1). According to the MMNP forest damage map distribution, the sampling location was determined after the 2010 Merapi eruption (BTNGM, 2011; Marhaento \& Kurnia, 2015). Five stands or samples of plants included roots, stems, leaves of $C$. mucunoides, and $V$. unguiculata were taken randomly in the plot of $20 \mathrm{~m} \times 100 \mathrm{~m}$ in each area with heavy, moderate, and minor damage. Five samples of the rhizosphere under the stands were taken (0-5 $\mathrm{cm}$ away from the stand with a depth of $0-20 \mathrm{~cm}$ ) (Muryati et al., 2016). Both the stands and the rhizosphere soil were wrapped in aluminum foil and plastic and observed in the Laboratory of Microbiology, Universitas Ahmad Dahlan Yogyakarta. Coordinate points and abiotic parameters,

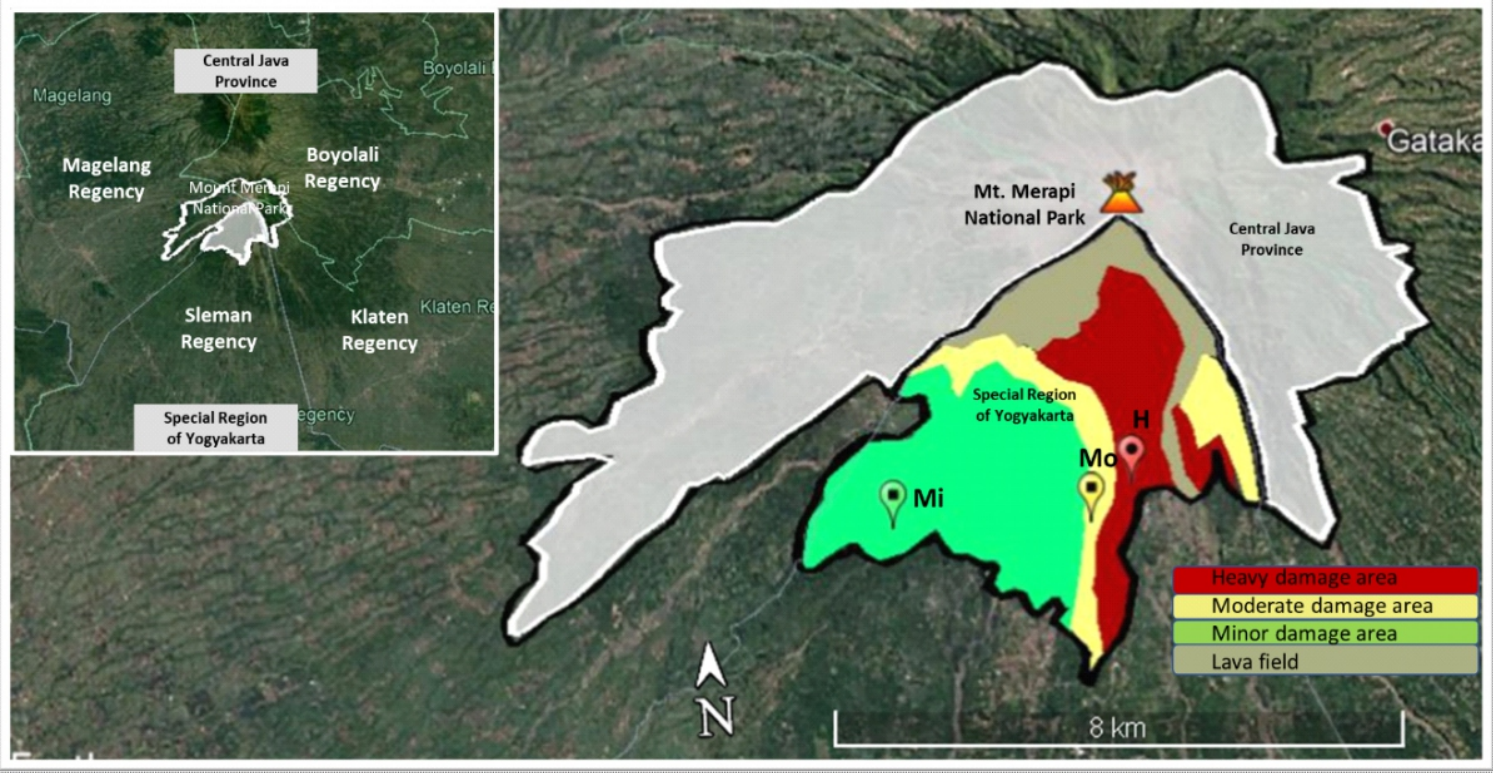

Figure 1 Sampling location in MMNP based on the distribution of MMNP forest damage map after the 2010 Merapi eruption. 
including soil temperature, soil $\mathrm{pH}$, soil moisture, soil profile, soil texture, slope, carbon organic soil, light intensity, and rainfall, were also measured in the plot (Syarif et al., 2007; Syib'ili et al., 2013).

AMF monitoring of root infection The methods used for root infection analysis were slide methods and root staining. Clean root samples were fixed with FAA solution for 1 hour to maintain cell and tissue shape (Suharno et al., 2014). The root cells were then immersed in $10 \% \mathrm{KOH}$ solution for 24 hours, soaked with $1 \% \mathrm{HCl}$ for 24 hours, and washed with distilled water to color the cells to be observed. Root samples were cut into pieces $1 \mathrm{~cm}$ in length (slide method), stained using lactophenol cotton blue for 24 hours (Abdel-fattah, 2001; Marques et al., 2013), dripped with lactoglycerin (destaining), and stored for 24 hours. Ten pieces of roots from each sample were observed by microscope. The presence of AMF was indicated by external hyphae, internal hyphae, vesicles, arbuscular, or spores. The colonization of AMF in roots could be calculated based on the number of all roots observed (Munarti et al., 2018) with the following formula as shown in Equation [1].

Percentage of root infections $=\frac{\text { Number of infected roots }}{\text { The number of all roots observed }} \times 100 \%$

Observation of AMF spores in soil samples Spore analysis was carried out by wet sieving methods, which filtering the spores were assisted by water to separate them from the soil. A total of $20 \mathrm{~g}$ of soil samples and $100 \mathrm{~mL}$ of water were stirred and allowed to stand for 5 minutes. Soil samples were filtered in a stratified sieve set (sizes of $500 \mu \mathrm{m}, 250 \mu \mathrm{m}, 149$ $\mu \mathrm{m}$, and $63 \mu \mathrm{m}$ respectively from top to bottom) with running water. The suspension held in the lower sieve was rinsed and collected in a jam bottle, then transferred to a microscope slide to be observed under a microscope, and its amount was counted (Suharno et al., 2014). According to Kivlin (2020), most of the AMF spores have a size between $60 \mu \mathrm{m}$ to 150 $\mu \mathrm{m}$, so that the spores in the rhizosphere of the two pioneer plants are expected to be optimally identified. Identification of AMF spores found in the rhizosphere is used to identify the types of AMF to the genus taxon. Validation of AMF spores was carried out by comparing with the AMF spore collection database on the International Culture Collection of (Vesicular) Arbuscular Mycorrhizal Fungi (INVAM) website.

Data analysis Data were analyzed quantitatively through statistical tests to determine the ratio of the abundance of AMF in the areas affected by Mount Merapi's eruption with heavy, moderate, and minor damage levels. Data were analyzed to determine the correlation between the abiotic parameters, the percentage of infection, and the number of AMF spores. The statistical test (inferential analysis) started with conducting normality and homogeneity tests (Utami \& Putra, 2020) as a condition for subsequent parametric and non-parametric tests with a confidence level of $95 \%$. The significance test results $>0.05$ on the normality and homogeneity test showed that data were normally distributed and homogeneous so that a parametric test had to be done. The significance test $<0.05$ on both parametric and nonparametric tests showed that the two pioneer plants comparison was significantly different, both in the percentage of spore infection and the number of spores.

\section{Results and Discussion}

AMF infection in root samples The AMF structure was found to have infected all the root samples of $C$. mucunoides and $V$. unguiculata. The AMF structures found were internal spores, internal hyphae, vesicles, and external hyphae. The highest percentage of AMF infection in the roots of $C$. mucunoides was found in areas of moderate damage (76\%), while the highest percentage of AMF infection in $V$. unguiculata was found in areas with minor damage (74\%) (Figure 2). AMF was identified to have infected both plants' roots in areas with heavy damage with a $66 \%$ infection rate. Based on Anova test results, the levels of damage by Mount Merapi's eruption did not significantly affect the percentage of AMF infection. This result is indicated by a significance of 0.803 for $C$. mucunoides and a significance of 0.805 for $V$ unguiculata.

The number and ability of AMF to infect host plant roots are supported by several environmental parameters. Abiotic in three research locations have a value range between $22-30{ }^{\circ} \mathrm{C}$ for soil temperature, $5.2-6.9$ for soil $\mathrm{pH}, 0-58 \%$ for soil moisture, $0-30^{\circ}$ for soil moisture, $0.94-5.33 \%$ for organic carbon soil, 531-2,445 lux for light intensity, and 1-55 mm for daily rainfall. According to BMKG (2021), daily rainfall with a range of $0.5-20 \mathrm{~mm}^{-1 a y}{ }^{-1}$ includes low intensity, $20-50 \mathrm{~mm}^{-1} \mathrm{yy}^{-1}$ includes moderate intensity, while 50-100 $\mathrm{mm}$ day $^{-1}$ includes heavy intensity. The correlation test results carried out on the percentage of AMF infection on the abiotic factor showed that in the area with moderate damage, AMF infection in the roots of C. mucunoides was correlated with a slope with a significance of 0.025 . In contrast, a minor damage area is correlated with light intensity with a significance of 0.025 . On the other hand, there was no significant correlation between AMF infection in $V$. unguiculata roots and the measured abiotic factors. AMF is an obligate parasite, so the surrounding environment directly affects the host plant (Munarti et al., 2018; Rochdjatun \& Sastrahidayat, 2011). The average slope of the soil at the minor and moderate damage areas was relatively high, namely $20.3^{\circ}$ to $21.3^{\circ}$, in contrast to the heavy damage area with an average slope of $2^{\circ}$. Soil slope can affect light intensity in a forest ecosystem (Molles, 2008). Even though the density and carbon stock of trees at the area of minor and

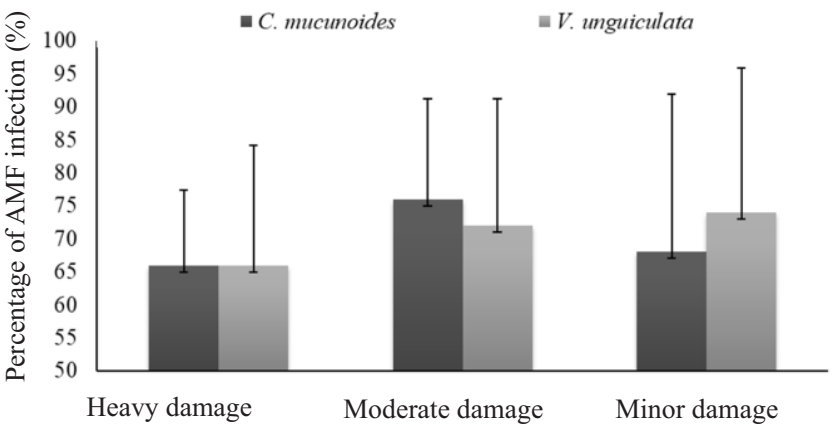

Figure 2 The percentage of AMF infection in the root samples of C. mucunoides and V. unguiculata. 
moderate damage is in the high category based on Reducing Emission from Deforestation and Forest Degradation or REDD+ (Yusuf, 2020), the average light intensity in two locations is relatively high, 1,295 lux and 1,276 lux. The average soil temperature at the minor and moderate damage areas ranges from $23^{\circ} \mathrm{C}$ and $26^{\circ} \mathrm{C}$, with soil moisture ranging from $53 \%$ and $30 \%$. The heavy damage area, which was still dominated by understorey plants (Husna, 2020), was recorded as having the highest light intensity, 1,873 lux, and recorded as having the highest soil temperature and the lowest soil moisture $30^{\circ} \mathrm{C}$ and $3 \%$. Light affects the photosynthetic process of host plants, especially $C$. mucunoides, which live in open areas with a high to low tolerance light intensity (500-10,000 lux), can live up to 2,000 $\mathrm{m}$ asl, and can live at low $\mathrm{pH}(4.5-5)$ (Syarif et al., 2007). The altitude and slope of an area will affect the host plant's growth and influence other abiotic factors (Suharno et al., 2014; Casazza et al., 2017). Abiotic factors such as soil temperature and humidity can directly influence the abundance and species of AMF in an ecosystem (Klironomos et al., 2001; Kivlin et al., 2011). AMF can be associated with $90-95 \%$ of plant roots scattered from the Arctic to the tropics and from deserts to forests (Kandari et al., 2016). The factors differentiating between regions are AMF and their host plants (De-Souza et al., 2012). The images of internal spores, internal hyphae, vesicles, and external hyphae that infect plant root samples can be seen in Figure 3.

Number of AMF spores in the rhizosphere The presence of spores in the rhizosphere of $C$. mucunoides and $V$. unguiculata will support the abundance of AMF in areas affected by Mount Merapi's eruption. The highest number of AMF spores was found in the area with minor damage where on average, the rhizosphere of $C$. mucunoides had 10.4 spores, and the rhizosphere of $V$. unguiculata had nine spores (Figure 4). Different levels of damage by the 2010 Merapi eruption did not significantly affect the average number of spores in the rhizosphere of $C$. mucunoides and $V$. unguiculata. This result is indicated by a significance of 0.801 for $C$. mucunoides and 0.083 for $V$. unguiculata. The presence of AMF in the areas affected by the 2010 Merapi eruption shows the role of AMF in the succession process. The spores in the rhizosphere of $C$. mucunoides and $V$. unguiculata can be seen in Figure 5.

The presence of AMF spores was validated with the INVAM website data. In C. mucunoides and $V$. unguiculata's rhizosphere, it can be concluded that there are five genera identified, namely Scutellospora, Sclerocystis, Glomus, Gigaspora, and Acaulospora. The spores in the genus Scutellospora and Gigaspores form a bulbous suspensor holder of hyphae, but the spores on Scutellopspora have an ornament germination shield (Nusantara et al., 2012). The spores in the genus Scleriocyctis are brown, forming a mark (sporocarp), and the outside is slippery (Tuheteru et al., 2019). Spores in the genus Acaulospora are light brown to dark brown and round (INVAM, 2017; Lee et al., 2018). The spores in the genus Glomus are oval, yellow with a slippery surface (INVAM, 2017). Genus Glomus dominates all study sites in both plants (Figure 6 and Figure 7), where the difference between the two plants lies in the genus that dominates the next. The rhizosphere $C$. mucunoides is further dominated by Acaulospora and Scutellospora, while in the rhizosphere, $V$. unguiculata is further dominated by Scutellospora and Gigaspora. According to Ansiga et al. (2017), the genus Glomus, Ascaulospora, and Sclerocystis were identified in other Fabaceae plants' rhizosphere
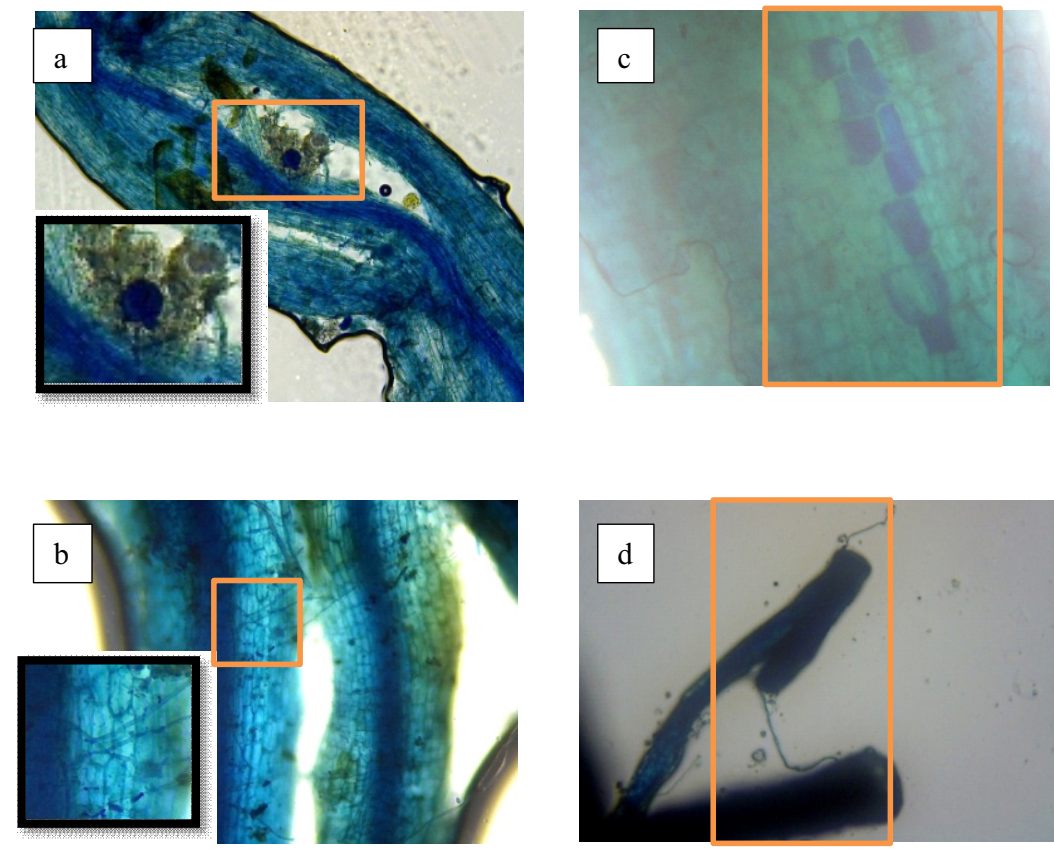

Figure 3 AMF structure in C. mucunoides and V. unguiculata from Fabaceae family with a magnification of 10: internal spores (a), internal hyphae (b), vesicles (c), external hyphae (d). 


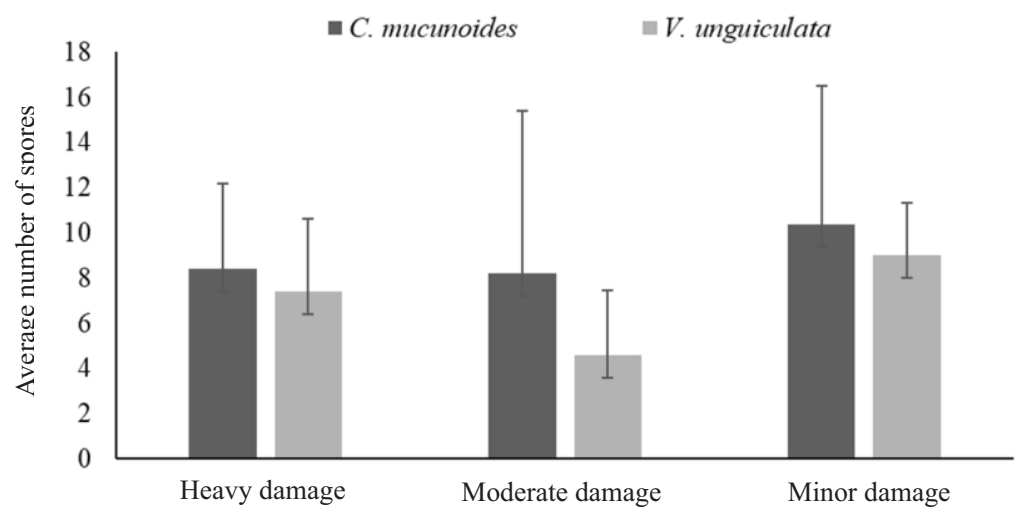

Figure 4 The average number of spores in the rhizosphere of $C$. mucunoides and $V$. unguiculata.
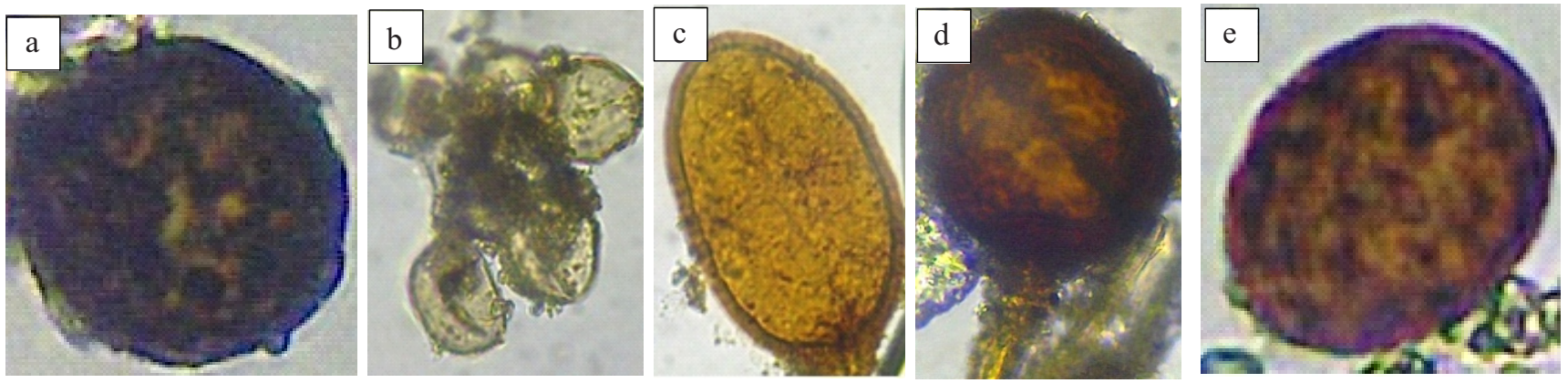

Figure 5 Spores in the rhizosphere of C. mucunoides and V. unguiculata (a-d) (magnification 100): Scutellospora sp. (a), Sclerocystis sp. (b), Glomus sp. (c), Gigaspora sp. (d), and Acaulospora sp. (e).

Leucaena leucocepala, Calliandra calothyrsus, and Gliricidia sepium. The number of spores in the plant rhizosphere, especially the Fabaceae family, can indicate a land's fertility (Syib'ili et al., 2013).

The results of the statistical tests showed that, in general, the average number of spores in the rhizosphere of $C$. mucunoides roots did not have any correlation with any abiotic factors, whereas $V$. unguiculata correlated with soil organic carbon with a significance of 0.016 and a correlation coefficient of $0.765^{*}$. On the other hand, the results of the correlation Pearson test at each damage level showed a correlation between the average number of spores in the root rhizosphere of $V$. unguiculata with soil $\mathrm{pH}$ with a significance of 0.033 and a correlation coefficient of $0.999^{*}$ and a correlation with rainfall with a significance of 0.033 and a correlation coefficient of $0.999^{*}$. Environmental factors, such as soil fertility and soil moisture, also influence the spore formation process (Rainiyati, 2007). Soil fertility can be described from the carbon organic soil (COS), where the average COS at minor damage area was $4.6 \%$, moderate damage area was $2.5 \%$, and heavy damage area was $2.0 \%$. AMF contributes to increasing soil organic carbon (Rillig et al., 2001; Ihsan et al., 2015). AMF not only actively participates in the carbon cycle by increasing the flow of carbon to the soil (Cardoso \& Kuyper, 2006) but also has a function as a bio activator in storing carbon in the rhizosphere through the glomalin structure in its body (Driver et al., 2005; Nusantara et al., 2012). Sampling was carried out at the end of the long dry season in December 2019, with monthly rainfall starting to enter the medium intensity of 100-150 mm (Prasetyaningtyas, 2020). During data collection, the average daily rainfall at minor damage area was $5.8 \mathrm{~mm}$ with a soil $\mathrm{pH}$ of 5.4 , while at moderate damage area, the average daily rainfall reached $34 \mathrm{~mm}$ with soil pH was 6.2. According to Odum (1993), rainfall and vegetation density above the soil surface affect soil moisture. The number of AMF spores varies according to the season, and the highest AMF colonization is during high rainfall conditions, while the highest number of spores is at the end of the dry season (Guadarrama et al., 2014). High rainfall can decrease the number of spores (Suharno et al., 2014), while fluctuations in soil moisture can affect spore formation or sporulation (Muhibuddin et al., 2014). Most AMF is acidophilic or optimally live in an environment with an 


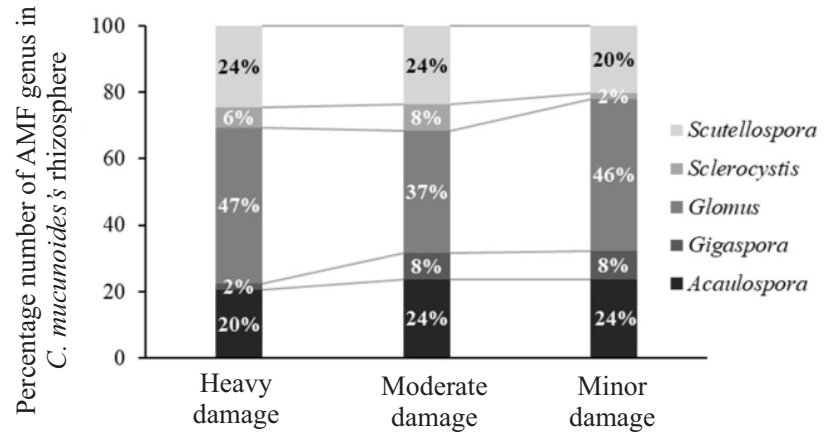

Figure 6 Percentage number of AMF genus in $C$. mucunoides's rhizosphere.

acidic pH (Saputra et al., 2015). The genus Glomus develop well on soils with pH 5.6-7, the genus Gigaspora with 4-6, and the genus Acaulospora with 4-5 (Tuheteru, 2003; Margarettha, 2011). The abundance of mycorrhizal spores is influenced by climatic factors, which will affect soil characteristics, physiology of the host plant, and the mycorrhizal symbiotic relationship (Octavianti \& Ermavitalini, 2014).

\section{Conclusion}

The highest mean percentage of AMF infection in $C$. mucunoides was found in the areas with moderate damage, with a percentage of $76 \%$. In comparison, V. unguiculata was found in minor damage areas with a percentage of $74 \%$. The highest number of AMF spores was found in the areas with minor damage, i.e., the rhizosphere of $C$. mucunoides had 10.4 spores, and the rhizosphere $V$. unguiculata had nine spores. Different damage levels did not significantly influence the percentage of AMF infection and the number of AMF spores. In C. mucunoides and $V$. unguiculata's rhizosphere, it can be concluded that there are five genera identified, namely Scutellospora, Sclerocystis, Glomus, Gigaspora, and Acaulospora, where the genus Glomus dominates all study sites in both plants.

\section{Recommendation}

Knowledge of the symbiotic relationship between pioneer plants and AMF in MMNP is essential to be studied further. The types of indigenous AMF in MMNP need to be further identified, where the forest ecosystem in MMNP is an ecosystem with high eruption disturbances. The rehabilitation process at MMNP can collaborate with local pioneer plants that have been inoculated by AMF so that survival opportunities can be increase.s Future research is expected to reach a wider area of MMNP to record more types of indigenous AMF symbiosis with more various local pioneer plants in MMNP.

\section{References}

Abdel-fattah, G. M. (2001). Measurement of the viability of arbuscular-mycorrhizal fungi using three different stains; relation to growth and metabolic activities of soybean plants. Microbiological Research, 156(4), 359-367.

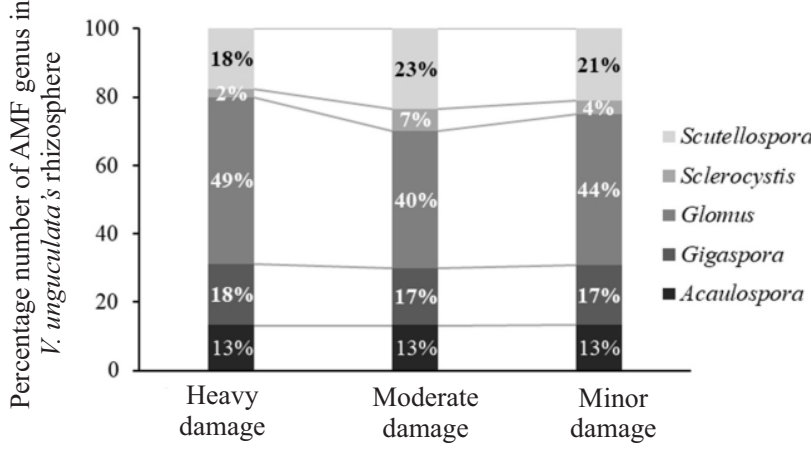

Figure 7 Percentage number of AMF genus in $V$. unguiculata's rhizosphere.

https://doi.org/10.1078/0944-5013-00121

Afrianto, W. F., Hikmat, A., \& Widyatmoko, D. (2016). Komunitas floristik dan suksesi vegetasi setelah erupsi 2010 di Gunung Merapi Jawa Tengah. Jurnal Biologi Indonesia, 12(2), 265-276. https://doi.org/10.14203/ jbi.v12i2.2895

Agus, C. \& Wulandari, D. (2012). The abundance of pioneer vegetation and their interaction with endomycorrhiza at different land qualities after Merapi eruption. Jurnal Manajemen Hutan Tropika, 18(3), 145-154. https://doi.org/10.7226/jtfm.18.3.145

Ansiga, R. E., Rumambi, A., Kaligis, D., Mansur, I., \& Kawunang, W. (2017). Eksplorasi fungi mikoriza arbuskular (FMA) pada rizosfir hijauan pakan. Jurnal Zootek, 37(1), 167-178. https://doi.org/10.35792/ zot.37.1.2017.14463

Barasa, F. R. (2013). Dampak debu vulkanik letusan Gunung Sinabung terhadap kadar $\mathrm{Cu}, \mathrm{Pb}$, dan $\mathrm{B}$ tanah di Kabupaten Karo. Jurnal Online Agroekoteknologi, 1(4), 1288-1297. https://doi.org/10.32734/jaet.v1i4.4422

Barea, J. M., Palenzuela, J., Cornejo, P., Sanchez-Castro, I., Navarro-Fernandez, C., Lopez-Garcia, A., ..., \& AzconAguilar, C. (2011). Ecological and functional roles of mycorrhizas in semi-arid ecosystems of Southeast Spain. Journal of Arid Environments, 75(12), 1292-1301. https://doi.org/10.1016/j.jaridenv.2011.06.001

Belay, Z., Vestberg, M., \& Assefa, F. (2013). Diversity and abundance of arbuscular mycorrhizal fungi associated with acacia trees from different land use systems in Ethiopia. African. Journal of Microbiology Research, 7 (48), 5503-5515. https://doi.org/10.5897/AJMR2013. 6115

[BMKG] Badan Meteorologi, Klimatologi, dan Geofisika. (2021). Probabilistik curah hujan 24 jam. Retrieved from https://www.bmkg.go.id/cuaca/probabilistik-curahhujan.bmkg.

[BTNGM] Balai Taman Nasional Gunung Merapi. (2011). 
Laporan restorasi ekosistem Merapi paska erupsi 2010. Yogyakarta: Balai Taman Nasional Gnung Merapi.

Cardoso, I., \& Kuyper, T. (2006). Mycorrhizas and tropical soil fertility. Agriculture, Ecosystems and Environment, 116, 72-84. https://doi.org/10.1016/j.agee.2006.03.011

Casazza, G., Lumini, E., Ercole. E., Dovana, F., Guerrina, M., Arnulfo, A., ..., \& Mucclarell1, M. (2017). The abundance and diversity of arbuscular mycorrhizal fungi are linked to the soil chemistry of screes and to slope in the Alpic Paleo-Endemic Berardia subacaulis. Plos One, 10(137), 1-18. https://doi.org/10.1371/journal.pone. 0171866

Cely, M. V. T., De oliveira, A. G., De Freitas Duin V. F., De Luca, M. B., Barazett, A. R., Dos Santos, I. M. O., ..., \& Andrade, G. (2016). Inoculant of arbuscular mycorrhizal fungi (Rhizophagus clarus) increase yield of soybean and cotton under field conditions. Frontiers in Microbiology, 7(720), 1-9. https://doi.org/10.3389/fmicb.2016.00720

Chen, M., Arato, M., Borghi, L., Nouri, E., \& Reinhardt, D. (2018). Beneficial services of arbuscular mycorrhizal fungi - From ecology to application. Frontier in Plant Science, 9(1270), 1-14. https://doi.org/10.3389/fpls. 2018.01270

Chitarra, W., Pagliarani, C., Maserti, B., Lumini, E., Siciliano, I., Cascone, P., \& Guerrieri, E. (2016). Insights on the impact of arbuscular mycorrhizal symbiosis on tomato tolerance to water stress. Plant Physiology, 171(2), 1009-1023. https://doi.org/10.1104/pp.16.00307

Da-Silva, M., Pescador, R., Rebelo, R., \& Sturmer, S. (2008). The effect of arbuscular mycorrhizal fungal isolates on the development and oleoresin production of micropropagated Zingiber officinale. Brazilian Journal Plant Physiology, 20, 119-130. https://doi.org/10.1590/ S1677-04202008000200004

Dell, B. (2002). Role of mycorrhizal fungi in ecosystem. CMU Journal, 1(1), 47-60.

De-Souza, L. A., de-Andrade, S. A., de-Souza, S. C., \& Schiavinato, M. A. (2012). Arbuscular mycorrhiza confers $\mathrm{Pb}$ tolerance in Calopogonium mucunoides. Acta Physiol Plant, 34, 523-531. https://doi.org/10.1007/ s11738-011-0849-y

Dewi, N. K., Susrama, I. K., Sritamin, M., Adnyana, M., \& Wirawan, I. P. (2014). Identification of arbuscular mycorrhizal fungi in rhizosphere soil of several grass species and cacao (Theobroma cacao L.) based on its spore morphological characteristics. International Journal of Biosciences and Biotechnology, 2(1), 26-31.

Dodd, J. C. (2000). The role of arbuscular mycorrhizal fungi in agro- and natural ecosystems. Agriculture, 29(1), 55-62. https://doi.org/10.5367/000000000101293059

Driver, J., Hoben, W., \& Rillig, M. (2005). Characterization of glomalin as a hyphal wall component of arbuscular mycorrhizal fungi. Soil Biology and Biochemistry, 37, 101-106. https://doi.org/10.1016/j.soilbio.2004.06.011

Ferrol, N., Tamayo, E., \& Vargas, P. (2016). The heavy metal paradox in arbuscular mycorrhizas: from mechanisms to biotechnological applications. Journal of Experimental Botany, 67(22), 6253-6265. https://doi.org/10.1093/ jxb/erw403

Gao, C., Montoya, L., Xu, L., Madera, M., Hollingsworth, J., Purdom, E., ..., \& Taylor, J. W. (2019). Strong succession in arbuscular mycorrhizal fungal communities. The ISME Journal, 13, 214-226. https://doi.org/10.1038/s41396018-0264-0

Guadarrama, P., Castillo, S., Ramos-Zapata, J., HernandezCuevas, L., \& Camargo-Ricalde, S. (2014). Arbuscular mycorrhizal fungal communities in changing environments: The effects of seasonality and anthropogenic disturbance in a seasonal dry forest. Pedobiologia, 57, 87-95. https://doi.org/10.1016/ j.pedobi.2014.01.002

Gunawan, H., Sugiarti, Wardani, M., Tata, M., \& Prajadinata, S. (2013). Restorasi ekosistem Gunung Merapi paska erupsi. Bogor: Pusat Penelitian dan Pengembangan Konservasi dan Rehabilitasi.

Hariani, F., \& Erlita. (2016). Pemberian mikoriza dan sludge untuk meningkatkan produksi tanaman kacang tanah (Arachis hypogaea L). Agrium, 20(1), 337-343.

Horn, S., Hempel, S., Verbruggen, E., Rillig, M. C., \& Caruso, T. (2017). Linking the community structure of arbuscular mycorrhizal fungi and plants: a story of interdependence? The ISME Journal Multidisciplinary Journal of Microbial Ecology, 11(6), 1400-1411. https://doi.org/10.1038/ismej.2017.5

Husna, F. (2020). Stok karbon dan keanekaragaman tumbuhan bawah pada variasi kerusakan hutan TNGM paska erupsi Merapi 2010 [thesis]. Yogyakarta: Universitas Ahmad Dahlan.

Ihsan, M. A. H. S., Guchi, H., \& Lubis, A. (2015). Hubungan ketinggian tempat dan C-organik tanah dengan infeksi FAM pada perakaran tanaman kopi (Coffea sp.) di Kabupaten Dairi. Jurnal Agroteknologi, 3(4), 1575-1584. https://doi.org/10.32734/jaet.v3i4.11809

[INVAM] International Culture Collection of (Vesicular) Arbuscular Mycorrhizal Fungi. (2017). Species descriptions from reference cultures. Retrieved from http://fungi.invam.wvu.edu/the-fungi/speciesdescriptions.html.

Kandari, A. M., Arif, A., Amalia, C., \& Kasim, S. (2016). Analisis keberadaan dan indeks keragaman cendawan mikoriza arbuskula (FMA) di areal Rhizosfer Kalapi (Kalappia celebica Kosterm) pada dua lingkungan tumbuh yang berbeda di Kabupaten Kolaka. Ecogreen, 


$$
\text { 2(1), 21-30. }
$$

Karti, P., Prihantoro, I., \& Setiana, M. (2018). Evaluation of arbuscular mycorrhizal fungi inoculum on production and nutrient content of Pennisetum purpureum. Tropical Animal Science Journal, 41(12), 114-120. https://doi.org/10.5398/tasj.2018.41.2.114

Khan, A. G. (2005). Role of soil microbes in Rizhospheres of plants growing on trace metal contaminated soils in phytoremediation. Journal of Trace Elements in Medicine and Biology, 18, 355-364. https://doi.org/ 10.1016/j.jtemb.2005.02.006

Kivlin, S. N. (2020). Global mycorrhizal fungal range sizes vary within and among mycorrhizal guilds but are not correlated with dispersal traits. Journal of Biogeography, 47(9), 1-8. https://doi.org/10.1111/jbi.13866

Kivlin, S. N., Hawkes, C. V., \& Treseder, K. K. (2011). Global diversity and distribution of arbuscular mycorrhizal fungi. Soil Biology and Biochemistry, 43, 2294-2303. https://doi.org/10.1016/j.soilbio.2011. 07.012

Klironomos, J. N., Hart, M. M., Gurney, J. E., \& Moutoglis, P. (2001). Interspecific differences in the tolerance of arbuscular mycorrhizal fungi to freezing and drying. Canadian Journal of Botany, 79, 1161e1166.

Kurnia, A. N. (2015). Refleksi 5 tahun paska erupsi Gunung Merapi 2010: Menaksir kerugian ekologis di kawasan Taman Nasional Gunung Merapi. Journal of Geometrics and Planning, 2(2), 68-81. https://doi.org/10.14710/ geoplanning.2.2.69-81

Lee, E. H., Park, S. H., Eo, J. K., Ka, K. H., \& Eom, A. H. (2018). Acaulosproa koreana, a new species of arbuscular mycorrhizal fungi (Glomeromycota) associated with roots of woody plants in Korea. Mycobiology, 46(4), 341-348. https://doi.org/10.1080/ 12298093.2018.1548805

Marfai, M. A., Cahyadi, A., Hadmoko, D., \& Sekaranom, A. (2012). Sejarah letusan Gunung Merapi berdasarkan fasies gunung api di Daerah Aliran Sungai Bedog Daerah Istimewa Yogyakarta. Riset Geologi dan Pertambangan, 22(2), 73-79. https://doi.org/10.14203/risetgeotam 2012.v22.59

Margarettha. (2011). Eksplorasi dan identifikasi mikoriza indigen asal tanah bekas tambang batu bara. Berita Biologi, 10(5), 641-647. https://doi.org/10.14203/ beritabiologi.v10i5.1923

Marhaento, H., \& Kurnia, A. N. (2015). Refleksi 5 tahun paska erupsi Gunung Merapi 2010: Menaksir kerugian ekologis di kawasan Taman Nasional Gunung Merapi. Geoplanning, 2(2), 69-81. https://doi.org/10.14710/ geoplanning.2.2.69-81

Marques, J. P. R., Soares, M. K. M., \& Appezzato-da-gloria,
B. (2013). New staining technique for fungal-infected plant tissues. Turkish Journal of Botany, 37, 14. http://doi.org/10.3906/bot-1204-9

Mensah, A. K. (2015). Role of revegetation in restoring fertility of degraded mined soils in Ghana: A review. International Journal of Biodiversity Conservation, 7(2), 57-80.https://doi.org/10.5897/IJBC2014.0775

Molles, M. C. (2008). Ecology: Concepts and applications (4th ed.). New York: Mc Graw Hill.

Muhibuddin, A., Nurhatika, S., \& Nurhalimah, S. (2014). Eksplorasi mikoriza vesikular arbuskular (MAV) indigenous pada tanah regosol di Pamekasan, Madura. Jurnal Sains Dan Seni Pomits, 3(1), 30-34. https://doi.org/10.12962/j23373520.v3i1.5526

Mulyana, D., \& Asmarahman, C. (2012). Untung besar dari bertanam sengon. Jakarta: AgroMedia Pustaka.

Munarti, Wulan, A., \& Utami, A. (2018). Exploration and identification of arbuscular mycorrhizal fungi from the Rhizosphere of Chili plants (Capsicum Annuum L.) in Bogor. Journal of Science Innovare, 1(2), 50-53. https://doi.org/10.33751/jsi.v1i02.1001

Muryati, S., Mansur, I., \& Wilarso, S. B. (2016). Keanekaragaman fungi mikoiza arbuskular (FMA) pada Rhizosfer Desmodium spp. asal PT. Cibaliung Sumberdaya, Banten. Jurnal Silvikultur Tropika, 7(3), 188-197.

Muryati. S., Mansur, I., \& Wilarso, S. B. (2017). Aplikasi fungi mikoriza arbuskula pada bibit Desmodium ovalifolium di lahan pasca tambang. Jurnal Perbenihan Tanaman Hutan, 5(1), 35-50. https://doi.org/10.20886/ bptpth.2017.5.1.35-50

Newhall, C., Bronto, S., Alloway, B., Banks, N., Bahar, I., del Marmol, M., \& Wirakusumah, A. (2000). 10,000 Years of explosive eruptions of Merapi Volcano, Central Java: Archaeological and modern implications. Journal of Volcanology and Geothermal Research, 100(14), 9-50. https://doi.org/10.1016/S0377-0273(00)00132-3

Nusantara, A. D., Bertham, Y. H., \& Mansur, I. (2012). Bekerja dengan fungi mikoriza arbuskula. Bogor: SEAMEO BIOTROP.

Octavianti, E. N. \& Ermavitalini, D. (2014). Identifikasi mikoriza dari lahan Desa Poteran, Pulau Poteran, Sumenep Madura. Jurnal Sains Pomits, 3(2), 53-57. https://doi.org/10.12962/j23373520.v3i2.6871

Odum, E. P. (1993). Dasar-dasar ekologi (Ed. 3). Yogyakarta: Gadjah Mada University Press.

Pahan, I. (2006). Panduan lengkap kelapa sawit. Bogor: Penebar Swadaya

Parwati, A. F., Aptari, Z., Saputri, R. D., Akbarudin, A. M., 
Kirana, A. G., \& Wahyuni, S. T. (2019). Analisis vegetasi di Taman Nasional Gunung Merapi. Jurnal Penelitian Ekosistem Dipterokarpa, 5(2), 107-112. https://doi.org/ 10.20886/jped.2019.5.2.107-112

Prasetyaningtyas, K. (2020). Analisis curah hujan dan sifat hujan Bulan Desember 2019. Retrieved from https://www.bmkg.go.id/iklim/informasi-hujanbulanan.bmkg? $p=$ analisis-curah-hujan-dan-sifat-hujanbulan-desember-2019\&lang=ID

Pujiastuti, E. (2018). 3 kayu cepat panen. Depok: PT Trubus Swadaya.

Purwanto, I. (2007). Mengenal lebih dekat Leguminoseae. Yogyakarta: Kanisius.

Putra, S. S., Putra, E. T. S., \& Widada, J. (2020). The effects of types of manure and mycorrhizal applications on sandy soils on the growth and yield of curly red chili (Capsicum annum L.). Journal of Sustainable Agriculture, 35(2), 258-267. https://doi.org/10.20961/carakatani.v35i2. 34971

Rainiyati. (2007). Status dan keanekaragaman cendawan mikoriza arbuskula (CMA) pisang raja nangka dan potensi pemanfaatannya untuk peningkatan produksi pisang asal kultur jaringan di Kabupaten Merangin, Jambi [thesis]. Bogor: Sekolah Pascasarjana IPB.

Requena, N., Perez-Solis, E., Azcon-Aguilar, C., Jeffries, P., \& Barea, J. M. (2001). Management of indigenous plantmicrobe symbioses aids restoration of desertified ecosystems. Applied and Environmental Microbiology, 67, 495-498. https://doi.org/10.1128/AEM.67.2.495498.2001

Rillig, M., Wright, S., Nichols, K., Schmidt, W., \& Torn, M. (2001). Large contribution of arbuscular mycorrhizal fungi to soil carbon pools in tropical forest soils. Plant and Soil, 233, 167-177. https://doi.org/10.1023/ A:1010364221169

Rochdjatun, \& Sastrahidayat, I. (2011). Rekayasa pupuk hayati mikoriza dalam meningkatkan produksi pertanian. Malang: Universitas Brawijaya Press.

Sajimin, Fanindi, A., \& Hutasoit, R. (2017). Pengaruh metoda penyimpanan terhadap viabilitas dan vigor benih calopo (Calopogonium mucunoides). Pastura, 6(2), 98-101. https://doi.org/10.24843/Pastura.2017. v06.i02.p12

Saputra, H., Rizalinda, \& Lovadi, I. (2015). Jamur mikoriza vesikular arbuskular (MVA) pada perakaran tanaman bawang mekah (Eleutherine americana Merr.). Protobiont, 4(1), 143-150.

Saputri, Y. E., \& Suwirmen, Z. A. (2016). Respon pertumbuhan tanaman Desmodium heterophyllum Willd D.C. dengan pemberian fungi mikoriza arbuskular
(FMA) pada tanah bekas tambang batubara Sawahlunto. Biocelebes, 10(2), 52-60.

Smith, S. E., \& Read, D. (2008). Mycorrhizal symbiosis (3rd ed.). New York: Academic Press, Elsevier.

Solomon, I., Oyebadejo, S., Udoh, U., \& Uyanga, V. (2014). Effect of feeding dumpsite forage calapo (Calopogonium mucunoides) on the histology of the kidney and liver of rabbits (Oryctolagus cuniculus). Journal of Agriculture and Environmental Sciences, 3(3), 91-104. https://doi.org/10.15640/jaes.v3n3a8

Suharno \& Sancayaningsih, R. P. (2013). Fungi mikoriza arbuskula: Potensi teknologi mikorizoremidiasi logam berat dalam rehabilitasi lahan tambang. Bioteknologi, 10(1), 23-34. https://doi.org/10.13057/biotek/c100104

Suharno, S., Sancayaningsih, R. P., Soetarto, E. S., \& Kasiamdari, R. S. (2014). Keberadaan fungi mikoriza arbuskular di kawasan tailing tambang emas Timika sebagai upaya rehabilitasi lahan ramah lingkungan. Jurnal Manusia dan Lingkungan, 21(3), 295-303. https://doi.org/10.22146/jml.18556

Sukmadi, R. (2013). Aktivitas fitohormon Indole-3-Acetic Acid (IAA) dari beberapa isolat bakteri rizosfer dan endofit. Jurnal Sains dan Teknologi Indonesia, 14(3), 221-227.https://doi.org/10.29122/jsti.v14i3.930

Suriadikarta, D. A., Abdullah, A. I., Sutono, Dedi, E., Edi, S., \& Kasno, A. (2011). Identifikasi sifat kimia debu volkan, tanah dan air di lokasi dampak letusan Gunung Merapi. Bogor: Balai Penelitian Tanah.

Sutomo. (2019). Acacia decurrens di sebagian kawasan Taman Nasional Gunung Merapi Yogyakarta. Jurnal AlAzhar Indonesia Seri Sains dan Teknologi, 5(1), 38-42. https://doi.org/10.36722/sst.v5i1.321

Syamsiyah, J., Sunarminto, B. H., Hanudin, E., \& Widada, J. (2014). Effect of arbuscular mycorrizhal fungi inoculation on glomalin, growth and rice yield. Journal of Soil Science and Agroclimatology, 11(1), 39-46. https://doi.org/10.15608/stjssa.v11i1.214

Syarif, F., Hidayati, N., \& Juhaeti, T. (2007). Potensi hipertoleransi Calopogonium mucunoides, Centrosema pubescens dan Cajanus cajan yang tumbuh pada limbah penambangan emas terkontaminasi sianida dan merkuri. Jurnal Biologi Indonesia, 4(4), 239-248. https://doi.org/ 10.14203/jbi.v4i4.3251

Syib'ili, M. A., Muhibuddin, A., \& Djauhari, S. (2013). Arbuscular mycorrhiza fungi as an indicator of soil fertility. Agrivita, 35(1), 44-53. https://doi.org/10.17503/ agrivita.v35i1.228

Talanca, H. (2010, July 2630). Status cendawan mikoriza vesikular-arbuskular (MAV) pada tanaman [Paper presentation]. Pekan Serealita Nasional, Maros, Indonesia. 
Taylor, J. D., Helgason, T., \& Öpik, M. (2017). Molecular community ecology of arbuscular mycorrhizal fungi. In J. Dighton, \& J. F. White (Eds.), The fungal community: Its organization and role in the ecosystem (4th ed.). Boca raton: CRC Press.

Trisilawati, O., Hartoyo, B., Bermawie, N., \& Pribadi, E. (2019, July). Application of AMF (Arbuscular Mycorrhizal Fungi) and organic fertilizer to increase the growth, biomass and bioactive content of Centella [Paper presentation]. The International Conference on Food Science and Technology, Semarang, Indonesia.

Tuheteru, F. D. (2003). Aplikasi asam humat terhadap sporulasi CMA dari bawah tegakan alami Sengon [thesis]. Bogor: Institut Pertanian Bogor.

Tuheteru, F. D., Husna, Albasri, Asrianti A., Sutri A. W., \& Kartini K. (2019). Arbuscular mycorrhizal fungi associated with adaptive plants in gold mine tailing. Biodiversitas, 20(11), 3398-3404. https://doi.org/ 10.13057/biodiv/d201137

Ulfa, M., Waluyo, E. A., \& Martin, E. (2006). Pengaruh inokulasi cendawan mikoriza arbuskular pada tanaman pulai di lahan bekas tambang batubara. Jurnal Penelitian Hutan Tanaman, 3(2), 101-106. https://doi.org/10.20886/ jpht.2006.3.2.101-106

Utami, I., \& Putra, I.L.I. (2020). Ekologi kuantitatif, metode sampling dan analisis data lapangan. Yogyakarta:
Penerbit K-Media.

Utami, I., Putra, R. A. P., Wibowo, M. S., Yusuf, F. I., Husna, F., Eko, A., \& Susanto, D. (2021a). Tree stratification based on eruption damage level in Mount Merapi National Park Yogyakarta Indonesia. Media Konservasi, 26(1), 71-81. https://doi.org/10.29244/medkon.26.1.7181

Utami, I., Yusuf, F. I., \& Husna, F. (2021b). Tree vegetation analysis after 10 years of Mount Merapi Eruption. Proceeding International Conference of Science and Engineering, 4, 33-40. Retrieved from http://sunankalijaga.org/prosiding/index.php/icse/article /view/616

Voight, B., Constantine, E., Siswowidjoyo, S., \& Torley, R. (2000). Historical eruptions of Merapi Volcano, Central Java, Indonesia, 17681998. Journal of Volcanology and Geothermal Research, (100), 69-138. https://doi.org/ 10.1016/S0377-0273(00)00134-7

Yurisman, B., Burhannudin, \& Wahdina. (2015). Asosiasi fungi mikoriza arbuskula (FMA) pada tanaman bintaro (Cerbera manghas Linn.) di tanah aluvial. Jurnal Hutan Lestari, 3(4), 551-560. https://doi.org/10.26418/ jhl.v3i4.13077

Yusuf, F. I. (2020). Analisis vegetasi dan stok karbon pohon pada variasi kerusakan hutan TNGM 10 tahun paska erupsi Merapi 2010 [thesis]. Yogyakarta: Universitas Ahmad Dahlan 